\title{
RUKUN: KEARIFAN LOKAL JAWA YANG MEMBIMBING PEMULIHAN MASYARAKAT PASCA GEMPA 2006
}

\author{
Endy Marlina ${ }^{1}$, Arya Ronald ${ }^{2}$, Sudaryono ${ }^{3}$, Atyanto Dharoko ${ }^{4}$ \\ ${ }^{1}$ Program Studi Arsitektur, Fakultas Sains dan Teknologi, \\ Universitas Teknologi Yogyakarta \\ Jl. Ring Road Utara Jombor Sleman Yogyakarta Telp 0274723310 \\ Email: endy_marlina@yahoo.com \\ 2,3,4 Jurusan Teknik Arsitektur dan Perencanaan, Fakultas Teknik, \\ Universitas Gadjah Mada, Jl. Grafika Yogyakarta
}

\begin{abstract}
ABSTRAK. Gempa yang melanda Daerah Istimewa Yogyakarta (DIY) dan sekitarnya pada bulan Mei 2006 yang lalu berakibat pada tumbuhnya Pasar Merdeka, salah satu wadah kegiatan ekonomi rakyat di Kabupaten Gunungkidul, DIY, sebagai alternatif wadah kegiatan ekonomi masyarakat Gunungkidul, menggantikan sementara Pasar Wonosari yang mengalami kerusakan. Tumbuh, berubah, dan berkembangnya ruang ekonomi rakyat ini menarik untuk dikaji lebih lanjut untuk mengetahui hal-hal apakah yang mendasari pemanfaatan ruang ekonomi rakyat tersebut. Studi ini dilakukan dengan metoda fenomenologi yang menekankan pada realitas keseluruhan untuk mengungkapkan makna transenden dibalik realitas yang tertangkap secara visual. Studi ini menemukan 'prinsip rukun' - pandangan dan tata nilai lokal masyarakat Wonosari dalam merespon ruang ekonomi di Pasar Merdeka yang didasarkan pada budaya Jawa. Prinsip rukun ini menjadi dasar konsep sosio kultural, sosio ekonomi, dan sosio politis dalam tata kehidupan masyarakat yang diimplementasikan secara fisik dalam sosio spatial. Temuan ini menggambarkan pengertian ruang sebagai space yang erat kaitannya dengan realitas fisik dan ruang sebagai place yang erat kaitannya dengan realitas psikologis, yang terbukti mampu membimbing masyarakat untuk cepat bangkit pasca bencana Gempa DIY, Mei 2006.
\end{abstract}

Kata kunci: budaya; kegiatan manusia; spasial; sistem setting

\section{"RUKUN": JAVANESE LOCAL WISDOM THAT GUIDE COMMUNITY'S RECOVERY POST-EARTHQUAKE 2006}

\begin{abstract}
Yogyakarta earthquake in May, 2006, caused the existence of the Merdeka Market, one of the people's economic activities supports in Gunungkidul Regency, Yogyakarta Special Territory, as an alternative economic activities support of Gunungkidul community, while the Wonosari market was being renovated. The growth, change, and development of this economic space is
\end{abstract}


interesting to be studied further to find out the factors that underlie the utilization of the economic space. This study was conducted with the phenomenology method, which emphasized the whole reality to explore the transcendent meaning behind the reality that was captured visually. This study revealed a 'principle of harmony', local community's values in response to the existence of the Merdeka Market, which is based on Javanese culture. The principle is the foundation pillars of three daily concepts; they are socio cultural, socio economic, and socio political concepts, which are physically implemented in the socio- spatial practice. These findings reveal the notion of space as a space which is closely related to the physical reality, and space as a place that is closely related to psychological reality, which proved to be able to guide the community to recover immediately after the earthquake in May, 2006.

Keywords: culture; human activities; spatial; setting system

\section{PENDAHULUAN}

Penciptaan ruang merupakan sebuah proses, dan proses tersebut berlanjut selama penggunaan sebuah ruang. Hal ini sesuai dengan pendapat Habraken (1998) bahwa setelah diciptakan, ruang akan tumbuh dan berkembang bersama dengan manusia yang menghuninya. Aktivitas inilah yang kemudian memberi nafas, makna, dan nilai pada ruang tersebut. Sedangkan terkait dengan bentuk fisiknya, proses penciptaan sebuah ruang juga didasari oleh ide dan gagasan yang merupakan refleksi dari pandangan-pandangan, pemikiran, dan tata nilai suatu masyarakat. Hal ini juga dinyatakan oleh Norberg Schulz, bahwa pengertian ruang dapat mencakup aspek fisik maupun aspek psikologis (Schulz, 1977). Hubungan antara ruang dan penghuninya (manusia) tersebut merupakan rekaman dari perjalanan hidup manusia yang apabila ditelusuri dapat memberikan gambaran perilaku manusia serta perubahannya selama kurun waktu penghunian ruang tersebut (Habraken, 1998). Schulz berpendapat bahwa sebuah 'ruang' dapat dilihat sebagai 'space' yang erat kaitannya dengan aspek fisik ruang - ruang merupakan suatu bentukan fisik yang dapat dilihat secara visual; dan dapat juga dilihat sebagai 'place' yang erat kaitannya dengan aspek psikologis - ruang merupakan wadah aktivitas manusia yang dapat merefleksikan tata nilai dan budaya menusia yang menggunakannya (Schulz, 1977).

Pada tanggal 27 Mei 2006, wilayah DIY dan sekitarnya diguncang gempa bumi yang cukup besar (6,9 skala Ritcher) yang menewaskan sekitar 5700 orang dan merusak lebih dari 140.000 bangunan. Bencana ini meninggalkan kerugian yang cukup besar khususnya di wilayah DIY dan Jawa Tengah, baik berupa kerugian jiwa dan fisik wilayah. Sektor ekonomi adalah salah satu sektor utama pendukung kehidupan manusia. Kegiatan ekonomi ini diwadahi dalam ruang-ruang ekonomi. Dalam peristiwa gempa bumi DIY 2006, masyarakat DIY yang sebagian besar merupakan masyarakat ekonomi lemah, terbukti mampu cepat bangkit 
kembali dan melakukan aktivitas kehidupannya sehari-hari. Proses ini ditunjang dengan berbagai kegiatan renovasi (perbaikan) dan rekonstruksi (pembangunan kembali) sarana permukiman dan pendukungnya, termasuk diantaranya adalah ruang ekonomi.

Salah satu ruang ekonomi yang mengalami pertumbuhan, perubahan, dan perkembangan pasca gempa 2006 adalah Pasar Merdeka di Kabupaten Gunungkidul. Pasar yang terletak di sebelah Pasar Wonosari ini tumbuh sebagai wujud respon masyarakat terhadap kerusakan Pasar Wonosari yang semula merupakan salah satu wadah kegiatan ekonomi rakyat penting di Kota Wonosari. Gempa 2006 berdampak pada kerusakan fisik Pasar Wonosari yang menyebabkan terhentinya kegiatan ekonomi rakyat di Pasar tersebut. Proses tumbuh dan berkembangnya Pasar Merdeka sebagai respon masyarakat lokal terhadap terhentinya kegiatan ekonomi rakyat menjadi hal yang menarik untuk dikaji dalam konteks keberdayaan masyarakat dalam menghadapi event bencana. Hal ini erat kaitannya dengan pola pikir dan latar belakang budaya masyarakat Wonosari.

\section{METODE PENELITIAN}

Penelitian ini bertujuan untuk mengeksplorasi sistem peruangan kegiatan ekonomi rakyat pasca gempa DIY 2006. Adapun ruang ekonomi rakyat yang dimaksud adalah ruang ekonomi rakyat di Pasar - merupakan wadah bagi kegiatan ekonomi masyarakat kebanyakan di Pasar. Pasar itu sendiri dilihat sebagai satu kesatuan fenomena, merupakan tempat berkumpul dan terjadinya transaksi antara penjual dan pembeli. Secara komprehensif Pasar akan meliputi pelaku aktivitas ekonomi (penjual, pembeli, pemasok barang, dan pengelola Pasar), ruang ekonomi (los, kios, fasilitas pendukung Pasar, dan ruang Pasar secara keseluruhan), dan aktivitas yang dilakukan di dalam lingkungan Pasar. Penyebutan 'sistem' pada peruangan kegiatan ekonomi rakyat adalah untuk menggambarkan keterkaitan antara manusia sebagai pengguna, aktivitas yang dilakukan, dan ruang yang mewadahinya. Sistem peruangan ekonomi rakyat merupakan keterkaitan antara lingkungan, ruang, dan aktivitas ekonomi. Sistem ini akan terkait erat dengan manusia sebagai aktor perencana, perancang, dan pengendali sistem. Karenanya, penelitian tentang sistem peruangan kegiatan ekonomi rakyat ini akan mencakup pola pikir dan budaya yang melatarbelakanginya.

Pengumpulan informasi dilakukan dengan dua pendekatan yaitu: 1) ruang sebagai place dan 2) ruang sebagai space. Pada pendekatan pertama ruang Pasar Merdeka akan dilihat dari sisi psikologisnya, sehingga akan terkait dengan aspek makna dan aspek nilai/harga. Pada pendekatan kedua ruang Pasar Merdeka akan dilihat dari sisi fisiknya sehingga akan terkait dengan aspek fungsi dan aspek struktur. Secara fisik informasi akan meliputi gambaran denah peruangan dan zona-zona untuk mengakomodasi fungsi-fungsi tertentu. Sedangkan secara non fisik informasi akan menggali respon/tanggapan pengguna terhadap sistem peruangan kegiatan ekonomi di Pasar Merdeka. Penggalian informasi dilakukan dengan cara pengamatan maupun wawancara. Penggalian informasi berjalan 
secara paralel dengan proses analisa. Titik masuk untuk menggali informasi dalam penelitian ini adalah: 1) Penataan ruang Pasar Merdeka yang meliputi penataan kios, los, dan ruang berdagang lainnya, serta penataan pasar secara keseluruhan, 2) Interelasi antara ruang Pasar dan kegiatan ekonomi rakyat, 3) Respon dan sikap masyarakat pengguna ruang Pasar terhadap ruang tersebut, dan 4) Aktivitas ekonomi di pasar. Titik masuk penggalian informasi tersebut bersifat tidak mengikat, dapat berkembang sesuai dengan kondisi lapangan.

Analisa dilakukan dalam dua tahap. Tahap pertama adalah analisa yang dilakukan secara induksi di lapangan. Proses analisa telah dimulai sejak subyek melakukan observasi terhadap obyek di lapangan, dalam kerangka mendalami obyek. Pada tahap ini, informasi-informasi yang berhasil dikumpulkan dari unit-unit informasi dikategorisasikan menjadi tema-tema. Analisa ini dilakukan secara terusmenerus dan berulang (iteratif) (Moleong, 2002). Berbagai informasi tentang Pasar Merdeka sebagai obyek diterima sebagai suatu bentuk keragamanan yang kemudian dikonstruksi ke dalam tema-tema. Tema-tema yang ditemukan dapat dianggap bersifat sementara yang selanjutnya dapat digunakan untuk mengarahkan penggalian data dan analisa berikutnya dalam upaya mengkonstruksi tema-tema sebagai temuan lapangan (Nasution, 1996). Tahap kedua merupakan kelanjutan dari tahap pertama, dimana tema-tema dianalisa secara induksi menjadi konsep-konsep. Konsep-konsep ini merupakan kekayaan lokal yang dengan pengkajian lebih lanjut dapat menggambarkan keberdayaan masyarakat dalam merespon dampak gempa 2006 khususnya dalam pemberdayaan aktivitas ekonomi rakyat.

\section{HASIL DAN PEMBAHASAN}

Pasar merupakan wadah kegiatan ekonomi yang dilakukan oleh masyarakat kebanyakan. Penataan pasar disesuaikan dengan karakter masyarakat sebagai pengguna ruang tersebut. Dalam konteks ruang ekonomi, pemanfaatan ruang tersebut disesuaikan dengan tuntutan kegiatan ekonomi - kegiatan yang mestinya mempunyai nilai keuntungan secara material bagi pelaku kegiatan tersebut. Dalam penggunaannya, ruang-ruang pasar dilengkapi dengan perlengkapan pendukung kegiatan sesuai kebutuhan para penggunanya. Hal ini disesuaikan dengan karakter dan sikap para penggunanya terhadap ruang tersebut.

Pasca gempa 2006, sebagian besar pedagang di Pasar Wonosari berpindah ke luar Pasar dan berdagang dengan ruang-ruang yang dibentuk secara darurat menggunakan tenda, karpet plastik, atau payung sebagai peneduh di sepanjang tepi jalan Wonosari. Hal ini berlangsung hingga hampir tiga bulan. Rusaknya Pasar Wonosari, meskipun tidak terlalu parah, dan terutama trauma masyarakat terhadap bencana gempa 2006 mengakibatkan para pedagang dan pembeli enggan masuk ke dalam Pasar selama beberapa waktu. Hal ini mengakibatkan suasana di sekitar Pasar Wonosari menjadi terlihat kumuh dan juga megakibatkan gangguan pada lalu lintas di Jalan Wonosari. Gejala ini kemudian ditanggapi oleh masyarakat Desa Madusari (desa tempat Pasar Wonosari berada) melalui karang 
tarunanya dengan memanfaatkan Lapangan Merdeka yang terletak di desa tersebut sebagai pasar baru dan membentuk organisasi pengelolanya.

Karang Taruna Desa Madusari prihatin melihat terganggunya aktivitas ekonomi masyarakat di sekitarnya. Kerusakan Pasar Wonosari dan trauma masyarakat terhadap bencana gempa mengakibatkan masyarakat (baik pedagang dan pembeli) enggan masuk ke Pasar Wonosari selama beberapa waktu. Ruang ekonomi kemudian tumbuh dan berkembang di sekitar Pasar Wonosari dan di tepian Jalan Wonosari, mengakibatkan kondisi sekitar Pasar menjadi kumuh dan lalu lintas Jalan Wonosari, jalan utama di Kota Wonosari terganggu. Ketidaknyamanan tersebut melahirkan insiatif Karang Taruna Desa Madusari untuk mengajak para pedagang berdiskusi. Karang Taruna kemudian melakukan pendekatan pada pemilik tanah lapangan Merdeka untuk menyewa sementara tanah tersebut. Diskusi antara Karang Taruna dengan para pedagang menghasilkan kesepakatan penyewaan tanah tersebut dan membaginya dalam kapling-kapling untuk dikelola sebagai Pasar sementara, menggantikan Pasar Wonosari yang rusak dan sedang direnovasi. Pasar itu kemudian disebut sebagai Pasar Merdeka.

Pasar Merdeka merupakan pasar baru yang dibangun dengan tujuan awal untuk melokalisir bakul-bakul (pedagang) dari Pasar Wonosari yang enggan kembali ke Pasar Wonosari pasca gempa 2006. Keengganan bakut-bakul tersebut kembali berdagang di dalam Pasar Wonosari terutama disebabkan oleh: a) trauma terhadap bencana gempa dan b) ketidaksesuaian penataan ruang Pasar pasca rekonstruksi (program pemerintah Kabupaten Gunungkidul pra gempa) dengan aspirasi bakul-bakul tersebut. Bencana gempa kemudian juga digunakan sebagai event untuk mendasari aksi relokasi ruang ekonomi rakyat tersebut. Penciptaan ruang di Pasar Merdeka ini menjadi hal yang menarik untuk dieksplorasi sebagai refleksi aspirasi dan kebutuhan bakul terhadap ruang ekonomi yang didasari oleh tata nilai dan budaya masyarakat tersebut.

Berdasarkan penelitian, secara implisit dapat ditangkap adanya respon/tanggapan pengguna terhadap ruang Pasar baik dalam tema mikro (kios/los) maupun dalam tema meso (Pasar). Secara umum, respon/tanggapan tersebut terkait dengan masalah akses/jalan keluar masuk dari/ke kios / los ke/dari area sirkulasi Pasar, ruang gerak penjual dan pembeli, tingkat interaksi antara penjual dan pembeli, penggunaan sarana pemajangan/penyimpanan barang dagangan, mobilitas barang dagangan, dan tingkat ketertutupan ruang. Gejalagejala ini menarik apabila digali lebih dalam untuk mengungkapkan alasan-alasan di balik gejala tersebut yang mungkin akan terkait dengan pola pikir, tata nilai, dan budaya masyarakat penggunanya. Lebih jauh lagi, apabila dikaitkan dengan fakta relatif cepatnya masyarakat Wonosari untuk pulih kembali dari gangguan dan kerusakan yang timbul karena peristiwa gempa DIY 2006. Perubahan tanggapan atau reaksi masyarakat terhadap ruang Pasar Merdeka mungkin mengandung budaya dan tata nilai lokal yang terkait dengan ketahahan masyarakat menghadapi bencana. 
Salah satu indikator pulihnya kehidupan masyarakat Wonosari pasca gempa 2006 dapat dilihat dari pulihnya sektor ekonomi rakyat. Hal ini mengindikasikan adanya pemanfaatan ruang Pasar yang relatif efektif (tepat guna) sehingga dapat mendukung upaya pemulihan kehidupan masyarakat Wonosari pasca gempa. Pertumbuhan dan perkembangan Pasar Merdeka juga menunjukkan upaya kontrol terhadap ruang yang berorientasi pada upaya survive. Dalam penelitian ini ditemukan beberapa budaya masyarakat yang mendasari respon/tanggapan terhadap ruang ekonomi rakyat (Pasar) sebagai berikut:

\section{Penyatuan Nilai Sosial Dan Ekonomi Dalam Ruang Ekonomi (Pasar)}

Lapangan Merdeka, sebuah lapangan di dekat Pasar Wonosari, pada awalnya merupakan area kosong yang lebih sering digunakan untuk aktivitas negatif bagi sebagian orang. Tanah kosong yang dimiliki oleh 2 orang warga ini kemudian disewa oleh organisasi pemuda dan dikelola menjadi kapling-kapling sewa sebagai alternatif tempat usaha bagi para pedagang yang membutuhkan lokasi berdagang yang relatif 'legal'. Adanya kebutuhan para pedagang dari Pasar Wonosari maupun pedagang kaki lima disekitar Pasar Wonosari mendorong terbentuknya ruang ekonomi baru yang dalam perjalanannya menjadi pasar informal. Saat ini, Lapangan Merdeka telah menjelma menjadi 'pasar informal' (Gambar 1) yang terbentuk dari kelompok tempat usaha bagi para pedagang yang berasal dari Pasar Wonosari dan para pedagang kaki lima yang memerlukan area usaha. Dalam perkembangannya, Pasar Merdeka disewa oleh sekitar 400 pedagang.

Dalam opersionalisasinya, ruang Pasar Merdeka dikembangkan dengan prinsip 'bisnis-sosial' dengan pertimbangan keberanian spekulasi. Menurut para penggunanya, prinsip ini mencakup pertimbangan-pertimbangan yaitu: kebutuhan para pedagang terpenuhi dan desa mendapatkan kontribusi dari opersional pasar tersebut. Sebagai komoditas 'bisnis-sosial', penetapan harga sewa kapling ditentukan berdasarkan beberapa pertimbangan yaitu: kemampuan sewa calon pengguna; nilai ekonomi kapling, terutama ditinjau dari posisi dan pencapaian lokasi oleh konsumen; dan luasan kapling (tidak seluruh kapling dibentuk dalam modul yang seragam, namun menyesuaikan dengan ketersediaan luas lahan di tempat tersebut). Berdasarkan pertimbangan di atas, direncanakan sistem subsidi silang pada penyewaan kapling untuk menyokong harga sewa tanah Lapangan Merdeka kepada pemiliknya yaitu $175 \%, 150 \%, 125 \%, 100 \%$, $85 \%$, dan $75 \%$. Masukkan dari penyewaan kapling dengan harga tinggi diharapkan dapat memberikan subsidi pada penyewaan kapling dengan harga rendah, sehingga dapat terjadi interaksi yang saling menguntungkan. Proses tumbuh dan berkembangnya Pasar Merdeka merupakan suatu proses politis dengan pertimbangan sosial yang kental. Pertimbangan dan persetujuan pengorganisasian Pasar menggambarkan intervensi nilai sosial dalam aktivitas politis.

Pasar Merdeka sebagai komoditas 'bisnis-sosial' merupakan salah satu wujud implementasi pendekatan pemanfaaran ruang dari aspek ekonomi dan fungsional (functional/economical approach) yang menekankan pada ruang sebagai wadah 
suatu kegiatan, dimana factor jarak dan lokasi menjadi penting; sekaligus dari aspek social-politik (socio-political approach) yang menekankan pada aspek 'penguasaan' ruang (Friedmann dan Weaver, 1979; Harvey, 1973). Aspek ekonomi dan fungsional dapat dilihat dari proses penyewaan dan pengorgasisasian lapangan Merdeka, yang sekaligus menunjukkan adanya pendekatan non ekonomi, yaitu pendekatan sosial yang sangat kental. Penerimaan stakeholder (pemilik tanah, pengurus Desa, Karang Taruna, masyarakat Desa, dan para pedagang) dengan konsolidasi merealisasikan pengorganisasian Pasar Merdeka menunjukkan kerelaan bersama dalam upaya mendukung usaha para pedagang untuk bangkit dan melakukan aktivitasnya seperti semula.

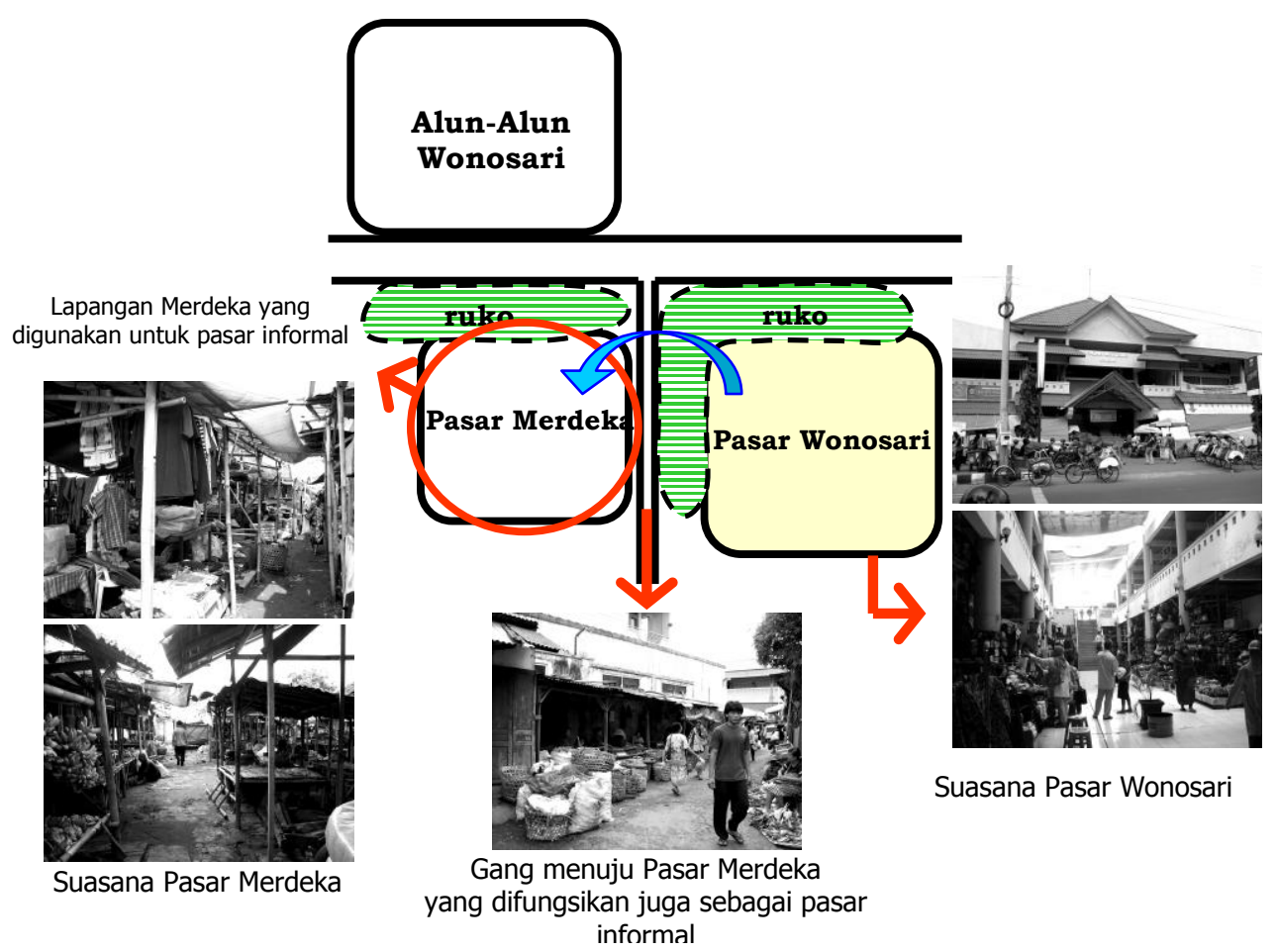

Gambar 1. Pasar Merdeka berkembang sebagai pasar informal, menggantikan peran Pasar Wonosari sebagai ruang ekonomi 
Sejumlah $85 \%$ dari pedagang yang beroperasi di Pasar Merdeka adalah penduduk yang berasal dari luar Desa Madusari meskipun pasar tersebut berlokasi di Desa Madusari. Penduduk Madusari yang bermata pencaharian sebagai pedagang, lebih memilih berdagang di luar pasar, terutama dengan ruang usaha yang lebih permanen. Hal ini didasari oleh adanya pemahaman bahwa pedagang di Pasar Merdeka tersebut digolongkan sebagai golongan masyarakat 'rendah', dalam arti secara sosial ekonomi masyarakat ini mempunyai kemampuan rendah, jauh di

bawah masyarakat asli Desa Madusari yang memandang dirinya sebagai 'priyayl (bangsawan).

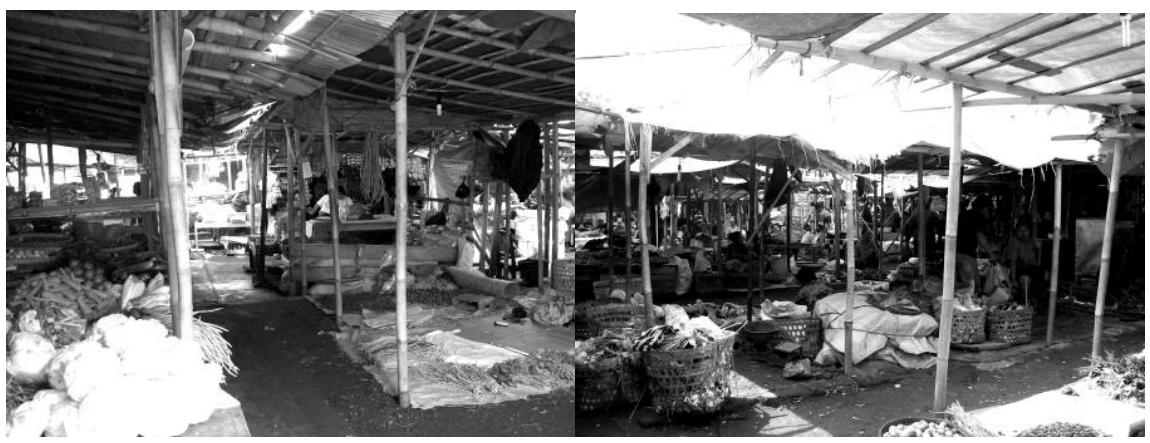

Gambar 2. Ruang privat (lapangan Merdeka) difungsikan sebagai ruang ekonomi (Pasar Merdeka) dengan sistem subsidi silang pada nilai sewanya sebagai penerapan prinsip rukun.

Pandangan ini juga mempengaruhi proses pembentukan organisasi pengelola Pasar Merdeka, dimana salah satu persyaratannya adalah 'penduduk asli Desa Madusari'. Dalam hal ini, 'priyayi' lah yang mempunyai hak membuat kebijakan terkait dengan nasib 'masyarakat bawah', golongan ekonomi lemah yang harus menghidupi dirinya dengan berjualan di pasar informal.

Pada kasus Pasar Merdeka, sebagian masyarakat mendasarkan pemanfaatan ruang ekonominya pada beberapa pertimbangan yaitu: a) kesempatan ada - dalam arti calon penyewa mengetahui adanya kesempatan menyewa ruang usaha di tempat tersebut; b) kondisi ekonomi mendukung - dalam arti secara ekonomi calon penyewa mampu membayar uang sewa dalam jumlah tertentu; c) pengelola pasar menyetujui - dalam arti pengelola pasar menyetujui dan membolehkan calon penyewa untuk menyewa tempat tersebut; d) pemilik lahan mengijinkan - dalam arti pemilik lahan mengijinkan tanahnya disewa dan dikelola menjadi pasar; e) pengurus desa mengijinkan - dalam arti pengurus desa yang membawahi lahan calon pasar mengijinkan penyewaan tempat tersebut dan mengelolanya menjadi pasar; dan f) Tuhan meridloi - dalam arti Tuhan meridloi usaha yang dilakukan di 
tempat tersebut dan melimpahkan rahmat-Nya pada usaha tersebut.

Dilihat dari proses terbentuknya, Pasar Merdeka merupakan sebuah pasar yang tumbuh karena ide dan motivasi masyarakat sendiri. Sepanjang proses pembentukannya, ditemukan beberapa hal menarik diantaranya terkait dengan cara pandang masyarakat terhadap komunitasnya sendiri dan komunitas lain, pertimbangan-pertimbangan yang mempengaruhi pemanfaatan ruang, cara menanggapi ruang, dan strategi yang ditempuh dalam upaya mengusung kesejahteraan bersama. Hal ini menunjukkan adanya pertimbangan-pertimbangan lain, selain pertimbangan ekonomi yang mempengaruhi proses pembentukan ruang ekonomi.

Menurut Schulz (1977), fenomena di atas menunjukkan adanya peran Pasar Merdeka sebagai implementasi nilai-nilai sosial (Social millieu). Peran ini memfungsikan Pasar Merdeka sebagai ekspresi status para pedagang dan masyarakat (melalui aksi Karang Taruna, warga, dan pengurus Desa) dalam merencanakan, memutuskan, dan mewujudkan ruang sebagai wadaj kegiatan mereka. Dengan peran ini Pasar mempresentasikan sistem sosial sebagai satu kesatuan. Selain itu, peran ini sekaligus merealisasikan komprehensifitas fungsi ekonomi, sosial, dan politik yang berlaku dalam masyarakat Wonosari.

\section{Intervensi Pertimbangan Sosial Dalam Aktivitas Ekonomi}

Bencana gempa bumi 2006 merupakan suatu event yang memberikan guncangan fisik dan psikis sangat hebat bagi sebagian besar masyarakat DIY. Kerugian fisik dan psikis ini juga menimbulkan trauma sosial bagi masyarakat. Pasca gempa 2006, sebagian besar masyarakat (yang semula memang sudah intensif melakukan kegiatan ekonomi di Pasar) memperpanjang waktunya berkegiatan ekonomi. Sedangkan pada sebagian masyarakat yang lain (yang semula belum intensif melakukan kegiatan ekonomi rakyat) berusaha membentuk ruang ekonomi rakyat sebagai salah satu cara untuk mendekatkan diri pada kebersamaan komunitas. Para pedagang lama cenderung memperpanjang waktu berdagangnya untuk mengurangi rasa kesepian yang dirasakan setelah mereka kembali ke rumahnya. Interaksi dan kebersamaan yang mereka dapatkan selama berdagang memberikan rasa lebih aman dan nyaman secara psikis karena mereka berada di tengah-tengah saudaranya, sehingga apabila terjadi suatu kejadian yang buruk, akan banyak saudara tempat mereka saling bergantung. Sebagian masyarakat yang semula bukan pedagang pun, kemudian mulai melakukan kegiatan berdagang sebagai sarana mendapatkan rasa kebersamaan yang memberikan rasa aman dan nyaman tersebut. Sebagian yang lain, yang tidak melakukan kegiatan berdagang, namun berperan sebagai pembeli pun memperpanjang waktunya berkegiatan di ruang ekonomi rakyat dengan melakukan interaksi sosial yang lain.

Fakta di atas menunjukkan meningkatnya kebutuhan masyarakat terhadap kebersamaan. Hal ini dirasakan dapat mengusir rasa kesepian dan ketakutan sebagai akibat trauma pada bencana gempa. Rasa senasib sepenanggungan ini 
juga meningkatkan budaya tolong-menolong dan mengeratkan persaudaraan. Persaudaraan bukan semata terbentuk karena adanya pertalian darah, namun lebih luas, justru terbentuk karena kesamaan nasib. Hal ini menunjukkan tingginya nilai sosial yang diagungkan dalam praktik interaksi diantara anggota masyarakat. Prinsip ini juga mendasari praktik-praktik kegiatan ekonomi yang dilakukan di Pasar. Pasar tidak saja difungsikan untuk mewadahi kegiatan ekonomi, namun juga berperan dalam pembentukan relasi sosial diantara penggunanya. Fakta ini juga mendeskribsikan menguatnya pertimbangan sosial dalam akttivitas ekonomi.

Pasca gempa 2006, dimana kebutuhan terhadap rasa kebersamaan meningkat, kadar nilai sosial yang dianggap sebagai hasil sampingan suatu kegiatan ekonomi juga mengalami peningkatan. Masyarakat semakin mementingkan terbentuknya nilai sosial sebagai hasil dari kegiatan ekonomi yang dilakukan. Pada beberapa kasus bahkan nilai sosial menempati ranking pertama dalam urutan macam keuntungan dari suatu kegiatan ekonomi. Peningkatan jumlah saudara merupakan hasil pokok dari suatu kegiatan ekonomi, menjadi dasar bagi sebagian orang untuk melakukan kegiatan ekonomi. Perolehan saudara menjadi pertimbangan penting (pada beberapa kasus justru menjadi yang utama) dalam melakukan praktik ekonomi. Pasar sebagai ruang ekonomi rakyat digunakan sebagai sarana untuk mewujudkan hal ini.

Pasar adalah ruang yang mewadahi kegiatan ekonomi, suatu kegiatan yang menghasilkan keuntungan. Membicarakan masalah keuntungan, dapat meliputi hal-hal yang bersifat material maupun non material. Keuntungan material adalah keuntungan utama yang dapat dipahami dengan mudah sebagai hasil dari suatu kegiatan ekonomi. Keuntungan ini dapat berupa uang ataupun barang yang mempunyai nilai ekonomi (dapat diuangkan). Keuntungan non material adalah keuntungan sampingan yang dihasilkan dari suatu kegiatan ekonomi. Dalam masyarakat Jawa dimana relasi sosial merupakan suatu komponen penting dalam praktik kehidupan sehari-hari, salah satu keuntungan non material yang didapatkan dari suatu kegiatan ekonomi adalah relasi sosial. Interaksi antar pelaku kegiatan adalah hal penting dalam praktik kegiatan ekonomi.

Peran Pasar Merdeka dalam mempresentasikan struktur kegiatan dalam manifestasi spasial menunjukkan karakter sebagai berikut: 1) organisasi ruang dalam bentuk kapling ruang, tanpa batasan fisik, 2) dimensi ruang menyesuaikan dengan kemampuan ekonomi calon penyewa. Hal ini didasarkan utamanya pada pertimbangan sosial. Prinsip rukun dalam interaksi masyarakat mengarahkan pengorganisasian ruang yang menampung fleksibilitas penataan ruang dan mengakomodir kebutuhan sosial para penggunanya, yaitu: 1) kebutuhan interaksi sosial secara intensif, 2) kebutuhan pengakuan bagian dari kelompok, 3) kebutuhan ketercukupan dukungan moral dalam dinamika hidup, dan 4) kebutuhan kebersamaan secara intensif. Hal ini mendeskribsikan simbolisasi budaya masyarakat Wonosari dalam tatanan fisik karya budaya masyarakat. Prinsip rukun tidak hanya direalisasikan dalam aktivitas keseharian, pun mengarahkan penciptaan karya fisik untuk mewadahinya. Pasar dalam hal ini 
mempunyai peran dalam simbolisasi budaya.

\section{Bercampurnya Relasi Ekonomi Dengan Relasi Sosial}

Relasi ekonomi terbentuk sebagai akibat dari dilakukannya kegiatan ekonomi. Kegiatan ekonomi yang dilakukan di pasar membentuk relasi ekonomi antar pedagang, pembeli, dan pemasok barang dagangan. Relasi ekonomi tersebut antara lain adalah a) relasi ekonomi antara penjual dan pembeli. Relasi ini terjadi karena adanya kegiatan jual beli. Penjual berkepentingan menjual barang dagangannya, dan pembeli berkepentingan untuk memiliki barang tersebut dengan cara membeli. Relasi ini dapat diklasifikasikan lagi menjadi: i) relasi antara penjual dan pembeli yang sudah saling kenal sebelumnya. Pada relasi ini, percakapan dan tegur sapa antara penjual dan pembeli berlangsung lebih intensif, lebih banyak dari pada sekedar tawar-menawar dalam transaksi jual beli. Tidak jarang mereka saling bertegur sapa, menanyakan kabar, atau bahkan menyampaikan pesan dari orang lain; ii) relasi antara penjual dan pembeli yang belum saling kenal sebelumnya. Pada relasi ini, percakapan terjadi sebatas tawar-menawar dalam transaksi jual beli. Kalaupun terjadi percakapan, pada awalnya hal itu dilakukan sekedar untuk bersopan-santun kepada calon konsumen, atau memang karena keramahtamahan pelaku ekonomi tersebut. b) relasi ekonomi antara penjual dan pemasok barang dagangan. Pada relasi ini, percakapan yang terjadi sebatas tawar-menawar dalam transaksi jual beli. Keakraban yang terjadi umumnya disebabkan karena umur jalinan relasi yang panjang. Selain itu, sebagian besar penjual maupun pemasok barang dagangan adalah individu yang ramah, mempunyai kemampuan membentuk relasi yang baik dengan lawan bicaranya. Sifat ini berdampak positif pada interaksi yang terjalin antara penjual dan pemasok barang dagangan meskipun para pemasok tersebut pada umumnya berasal dari luar daerah. Relasi-relasi di atas adalah relasi primer yang secara umum terjadi di ruang ekonomi manapun.

Selain relasi-relasi di atas, juga terjadi relasi ekonomi sekunder yang sekaligus dimanfaatkan untuk mempererat relasi sosial diantara para pelaku ekonomi di pasar. Di Pasar Merdeka diadakan kegiatan 'arisan'. Arisan adalah kegiatan menyimpan/menitip uang pada penyelenggara dalam jangka waktu tertentu. Besarnya uang dan jangka waktu titipan sudah ditentukan sebelumnya. Setiap periode pembukaan arisan/penarikan uang titipan, jumlah penariknya juga sudah ditentukan. Urutan peserta penarik dapat saja diundi di awal kegiatan (berupa nomor urut penarikan) atau diundi pada setiap periode penarikan uang titipan. Penitipan dan pembukaan arisan/penarikan uang titipan ini dilakukan berulangulang sehingga semua penitip sudah menarik uangnya. Kegiatan arisan ini dapat diikuti oleh siapapun baik penjual, pembeli, maupun pemasok barang dagangan. Kegiatan ini digemari karena beberapa hal yaitu: a) kegiatan arisan dipersamakan dengan kegiatan menabung yang praktis karena penarikan uang titipan dilakukan dengan cara jemput bola oleh penyelenggara arisan; b) kegiatan arisan menambah keakraban, merupakan salah satu sarana berkumpul atau berinteraksi antara sesama pelaku ekonomi; c) kegiatan arisan meningkatkan motivasi datang ke 
pasar, membentuk 'harapan (pengarep-arep)' bagi para peserta, yaitu harapan bahwa suatu ketika ada sejumlah uang yang akan diterima yang dapat digunakan untuk suatu keperluan. Di Pasar Merdeka diadakan beberapa kegiatan arisan oleh beberapa penyelenggara. Periode/jangka waktu pembukaan arisan/penarikan uang titipan bervariasi. Penyelenggara arisan pada umumnya berasal dari penjual di Pasar Merdeka atau pelaku ekonomi lain yang memang sering beraktivitas di Pasar Merdeka dan sudah dikenal oleh para pelaku ekonomi di Pasar tersebut.

Fakta di atas menunjukkan variasi relasi yang terjadi di Pasar sebagai ruang kegiatan ekonomi rakyat. Relasi yang terjadi tidak saja yang bersifat ekonomis, namun juga banyak relasi lain yang sifatnya non ekonomis, misalnya relasi sosial. Hal ini menunjukkan eratnya kaitan antara aktivitas ekonomi dan aktivitas sosial pada masyarakat itu. Fakta tersebut juga menunjukkan inisiatif masyarakat dalam bentuk strategi pemenuhan kebutuhan hidup. Sistem arisan yang dapat dipersamakan dengan menabung merupakan strategi ekonomi yang disenangi masyarakat karena selain merupakan strategi ekonomi juga merupakan strategi sosial untuk mempererat interaksi antar anggota masyarakat.

Tujuan penggunaan ruang di Pasar Merdeka tidak semata-mata terbatas pada tujuan ekonomi. Hal ini menjadi semakin menarik manakala dikaitkan dengan pemahaman lain, bahwa manusia adalah mahkluk yang berbudaya. Dalam hal ini, kegiatan manusia merupakan realisasi dari budaya yang dianutnya. Pemanfaatan suatu ruang oleh satu atau sekelompok manusia dapat pula menunjukkan implementasi dari budaya yang dianut oleh masyarakat tersebut.

\section{KESIMPULAN}

Tumbuhnya Pasar Merdeka sebagai respon masyarakat terhadap terganggunya aktivitas ekonomi di Pasar Wonosari pasca gempa 2006 menunjukkan berdayanya masyarakat Desa Madusari. Fakta ini menunjukkan kemandirian masyarakat, yang menunjukkan adanya kondisi dinamis yang memungkinkan masyarakat mampu membangun diri dan lingkungannya berdasarkan potensi, kebutuhan aspirasi, dan kewenangan yang ada pada masyarakat sendiri. Tentunya hal ini juga didukung dan difasilitasi oleh pengelola desa, yang juga merupakan bagian dari masyarakat itu sendiri.

Proses pertumbuhan Pasar Merdeka berdasarkan inisiatif masyarakat merupakan proses pengembangan kemampuan dan kemandirian masyarakat untuk berperan aktif dalam dalam upaya survive pada peristiwa bencana gempa 2006. Hal ini ditujukan agar secara bertahap masyarakat mampu membangun diri dan pulih pada kondisinya semula. Selain itu, keberdayaan masyarakat ini juga merupakan proses pemantapan nilai-nilai sosial budaya masyarakat. Adanya keterkaitan yang erat antara kegiatan ekonomi di Pasar Merdeka dengan kegiatan lain dalam kehidupan masyarakat (misanya social, budaya) menunjukkan bahwa kemandirian masyarakat mencakup hampir seluruh aspek kehidupan yaitu aspek ekonomi, dan sosial budaya. Dalam proses pertumbuhan dan perkembangan Pasar Merdeka, pada dasarnya masyarakat menempuh strategi (dikembangkan dari 
Checkoway, 1995): a) pengembangan aspirasi dan partisipasi masyarakat, b) pengorganisasian dan pelembagaan masyarakat, c) pemberdayaan masyarakat.

Tatanan fisik Pasar Merdeka yang mendeskribsikan budaya dan tata nilai masyarakat Wonosari. Prinsip kerukunan dan nilai-nilai social merupakan hal yang dijunjung tinggi yang mengarahkan pengorganisasian ruang Pasar Merdeka. Bahkan fungsi ekonomi yang merupakan fungsi pokok dalam suatu ruang ekonomi pun diintervensi secara signifikan oleh pertimbangan social. Hal ini menunjukkan eratnya keterkaitan antara aspek ekonomi, social, dan juga politik dalam kehidupan masyarakat Wonosari. Fakta ini utamanya menggambarkan kebutuhan masyarakat yang secara dominan berorientasi pada love, belonging need (dalam diagram Maslow (1943) berada pada tingkat 3), kebutuhan yang terkait erat dengan aspek sosial. Masyarakat butuh rasa dimiliki dan diterima oleh kelompoknya. Masyarakat membutuhkan teman, persahabatan, keakraban. Apabila tidak mendapatkan kebutuhan ini seseorang akan merasa kesepian. Kebutuhan ini bahkan lebih dominan dibandingkan dengan kebutuhan terhadap rasa aman (dalam diagram Maslow (1943) berada pada tingkat 2), meskipun pada beberapa aspek kebutuhan terhadap rasa aman ini saling mempengaruhi dengan love, belonging need. Fakta ini menunjukkan diagram yang berbeda dengan diagram Maslow, dapat dilihat pada gambar 3.

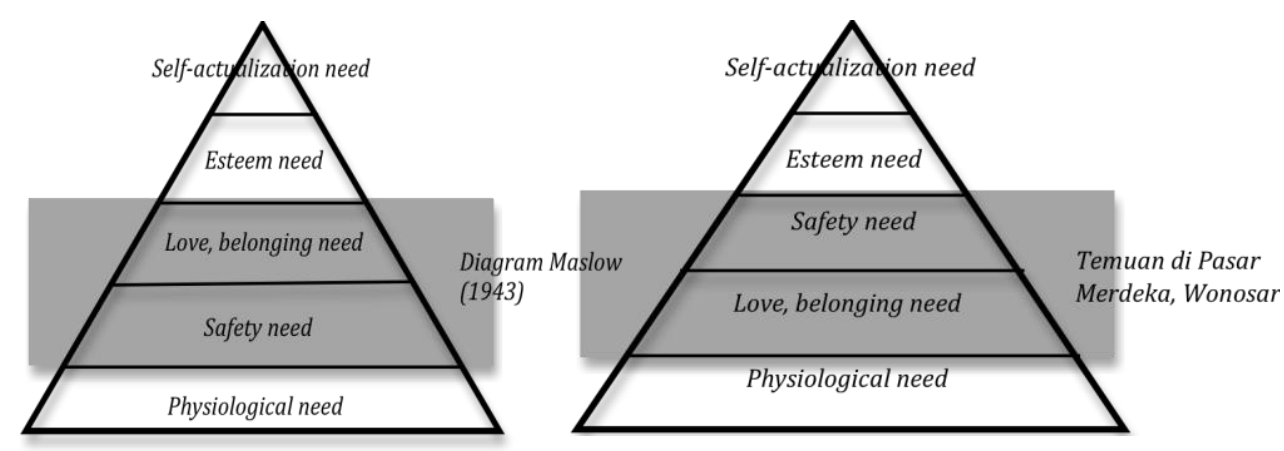

Gambar 3. Perbandingan tingkatan kebutuhan manusia berdasarkan temuan di Pasar Merdeka dengan diagram Maslow

Proses tumbuh dan berkembangnya Pasar Merdeka menunjukkan peranan Pasar tidak hanya sebagai ruang ekonomi, namun praktik bisnis-sosial tersebut juga mendeskribsikan pengertian sosio spasial yang ada dalam masyarakat. Proses pembentukan Pasar yang semestinya merupakan aktivitas politik, pada Pasar merdeka juga mendeskribsikan pengertian sosio politis yang ada dalam masyarakat. Temuan-temuan di atas menunjukkan bahwa prinsip rukun merupakan konsep dasar yang mewarnai komprehensifitas pemikiran masyarakat dan implementasiya dalam keseharian. Temuan ini dapat digambarkan dalam gambar 4. 


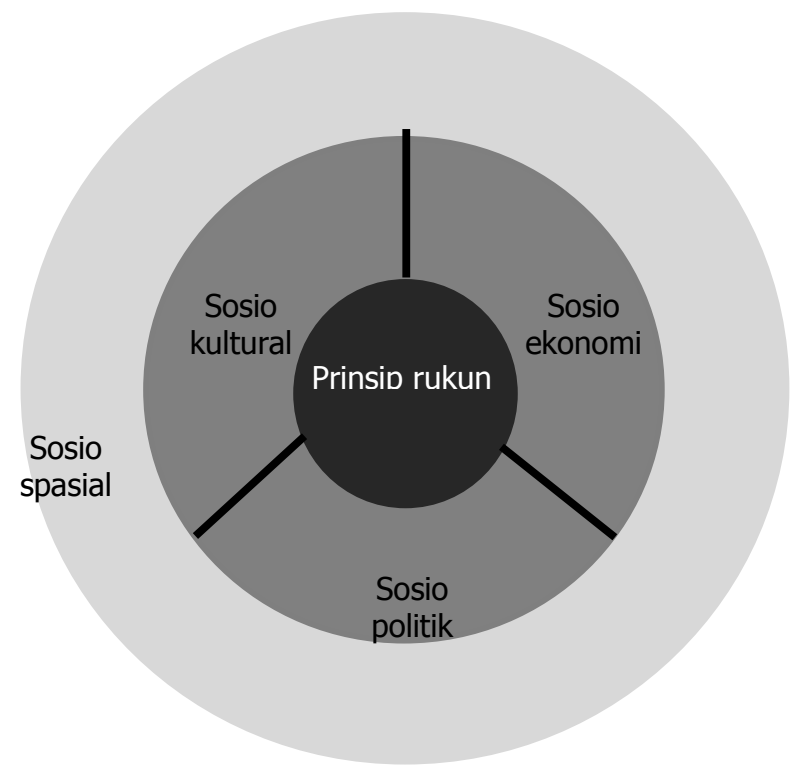

Gambar 4. Prinsip rukun sebagai dasar implementasi sosio ekonomi, sosio cultural, dan sosio politik, yang melahirkan sosio spasial

\section{DAFTAR PUSTAKA}

Checkoway, B. (1995), "Six Strategies of Community Changes", Community Development Journal (30)1

Habraken, (1998), "The Structure of the Ordinary: Form and Control in the Built Environment", USA: Graphic Composition Inc

Marlina. E, (2007a), "Penataan Ruang Sebagai Salah Satu Upaya Mitigasi Bencana Pada Gempa Bumi DIY 2006", Yogyakarta: Gadjah Mada University

Marlina. E, (2007b), "Perubahan Ruang Ekonomi Rakyat Pasca Gempa Yogyakrta Mei 2006, Kasus: Pasar Wonosari, Pasar Piyungan, dan Pasar Bantul, DIY", Yogyakarta: Gadjah Mada University

Moleong, Lexy J, (2002), "Metodologi Penelitian Kualitatif", Cetakan ke XVI, Bandung: PT Remaja Rosdakarya

Nasution, S., (1996), "Metode Penelitian Fenomenologi - Kualitatif", Bandung: Tarsito

Schulz, Christian-Norberg, (1977), "The Intention in Architecture", New York: Rizolli. 